\title{
Survey of echinoderms in the intertidal zone of Goso-on and Vinapor, Carmen, Agusan del Norte, Philippines
}

\author{
Angelo Mark P. Walag ${ }^{1 *}$, Archie G. Layaog ${ }^{1,2}$, Genevieve U. Garcia ${ }^{1,3}$ \\ ${ }^{1}$ Department of Science Education, University of Science and Technology of Southern Philippines, Cagayan de Oro City, Philippines \\ ${ }^{2}$ Senior High School in Carmen, Agusan Del Norte, Philippines \\ ${ }^{3}$ Balulang National High School, Cagayan de Oro City, Philippines \\ ${ }^{*}$ Corresponding author, E-mail: walag.angelo@gmail.com
}

\begin{abstract}
The health status of marine ecosystems can be fundamentally determined by the abundance and diversity of marine echinoderms. Philippines as part of the Indo-Pacific region is very rich and diverse in echinoderm species. In this study, the echinoderms of the intertidal zone of Goso-on and Vinapor, Carmen, Agusan del Norte were collected and identified. A total of 18 species were identified; five sea stars (Asteroidea), six sea urchins (Echinoidea), and seven sea cucumbers (Holothuroidea). Protoreaster nodosus, Linckia laevigata, and Diadema setosum were found to be abundant based on visual observation. The asteroids and echinoids collected were not yet assessed by the IUCN while the seven sea cucumbers were either least concern or data deficient. It is good to note that Holothuria scabra, an endangered sea cucumber was present in one sampling site. The low diversity, compared to some related studies, might suggest that exploitation is predominant particularly for sea cucumbers, considered a local delicacy. It is recommended that further studies must be conducted to evaluate the population of Holothuria scabra and other marine organisms to further evaluate the health of this marine ecosystem. Efforts must also be increased to further protect and conserve the marine faunal diversity of the study area.
\end{abstract}

Key words: Asteroidea, echinoderms, Echinoidea, endangered species, Holothuroidea, Philippines.

\section{Introduction}

Coastal areas serve as the interface between water draining from inland bodies of water and the oceans, receiving high concentrations of various natural and anthropogenic materials which includes inorganic and organic nutrients, soil and sediments, and pollutants (Sithik et al. 2009; Walag, Canencia 2016). These kinds of wastes can directly or indirectly affect the diversity, abundance, and distribution of marine organisms (Müller et al. 1995). Given this information, marine organisms present in the coastal areas therefore can serve as indicators of pollutants since they can respond quickly to changes in their habitats (Walag, Canencia 2016).

The marine organisms inhabiting coastal ecosystems include species cutting across different taxa of Porifera, Cnidaria, Annelida, Mollusca, Crustacea, Echinodermata, and Arthropoda to name a few. Of these taxa, echinoderms are considered important marine organisms having both economic and ecological value (Tuapattinaja et al. 2014). This phylum consists of five classes: Asteroidea (sea stars), Echinoidea (sea urchins), Holothuroidea (sea cucumbers), Ophiuroidea (brittle stars), and Crinoidea (feather stars). Ecologically, species of this taxon are detritus feeders, providing a vital link between available unused organic materials in the detritus and larger marine organisms (Hernández et al. 2006). Furthermore, these organisms are considered important predators of different attached marine life like barnacles and other invertebrates like clams (Bos et al. 2008). Economically, echinoderm species are considered as important source of food and medicine, especially sea cucumbers (Bordbar et al. 2011; Walag 2017). Members of echinoidea and asteroidea have also been found to have potential lead components in developing and producing novel drugs (Walag 2017). Meanwhile, sea stars are also sold and traded as souvenirs and ornaments (Bos et al. 2008) and sea urchins for its gonads, considered as a delicacy by the locals (Llacuna et al. 2016).

Echinoderms inhabit benthic communities, particularly the intertidal zone (Walag, Canencia 2016). This area is constantly threatened due to the amount of natural and human-produced materials and toxic substances carried onto it (Sithik et al. 2009). Furthermore, various anthropogenic activities that can affect the physicochemical factors such as temperature, salinity, and $\mathrm{pH}$ can dramatically drive the abundance and distribution of echinoderm species down (Walag, Canencia 2016). Not only their abundance and distribution is affected but also their growth rate, metabolic activity, immune response, and reproductive success (Lawrence, Herrera 2000). Due to these foregoing threats, some species are pushed to the verge of extinction and some species may have not even been studied nor recorded yet (Achacoso et al. 2016). Information regarding this taxon in this particular 
region of the country is still deficient and lacking. Thus, baseline data is needed on echinoderms present and their conservation status is important to help in the development policies to protect, manage and consolidate different resources available regarding legal conservation status of these organisms. The main aim of this study is to collect and identify echinoderms in the intertidal zone of Goso-on and Vinapor, Carmen, Agusan del Norte, Philippines.

\section{Materials and methods}

\section{Study area}

The study was conducted in the intertidal zone of Gosoon and Vinapor, Carmen, Agusan del Norte, Philippines as shown in Fig. 1. The Municipality of Carmen is located in the province of Agusan del Norte of CARAGA Region or Region XIII. It is strategically located along the Western Agusan Corregidor, surrounded by the Butuan Bay in the north, Buenavista in the south, Nasipit in the east, and Misamis Oriental in the west. The geography of this municipality is characterized by a rolling hills planted by different kinds of orchard, 500 hectares of which are devoted to mango plantations.

The coastline of Barangays Goso-on and Vinapor was divided into eight sampling plots (Fig. 1) along a transect parallel to the shore line. The sampling plots were established $40 \mathrm{~m}$ from the shore line and were $50 \mathrm{~m}$ apart. The respective coordinates of each sampling plot is shown in Table 1. Each sampling plot has a diameter of $2.5 \mathrm{~m}$. Sampling was performed twice, July 9, 2017 and October 7, 2017 during their respective low tide.

\section{Collection and identification of echinoderm species}

Echinoderms present in each sampling plot were recorded and identified. Two to three representative samples per species were collected using tweezers and tongs and were preserved using 10\% formaldehyde solution (Llacuna et al. 2016). The collected samples were brought to the laboratory for further identification using morphological characteristics with the aid of available literature (Clark, Rowe 1971; Barnes 1987; Vandenspiegel et al. 1998; Schoppe 2000; Stöhr et al. 2012; Pechenik 2015).

\section{Results and discussion}

\section{Echinoderm composition}

Echinoderm species along the intertidal zone of Gosoon and Vinapor was surveyed, collected and identified. A total of 18 species were identified from classes Asteroidea (5 species), Echinoidea (6 species), and Holothuroidea (7 species). Table 2 summarizes the identified echinoderms collected in the eight sampling sites. Majority of the number of species identified belong to class Holothuroidea although in terms of abundance and density, class Asteroidea had the most based on visual observation,

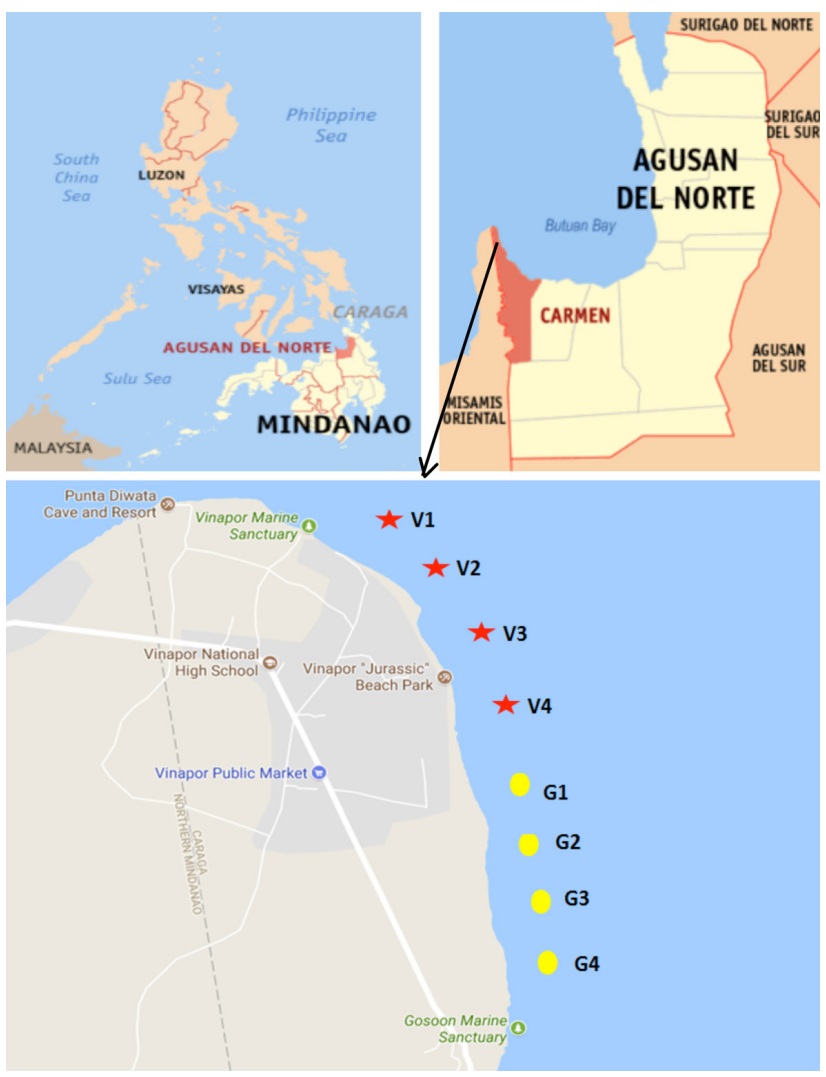

Fig. 1. Geographic location (top) and establishment of sampling sites (bottom) in Goso-on and Vinapor, Carmen, Agusan del Norte.

which is similar to the results of Llacuna et al. (2016) and Alvarado et al. (2012). The abundance and diversity of Asteroidea and Echinoidea can be attributed to the relatively good cover of seagrass and corals, which serve as both food and habitat for these organisms (Alvarado et al. 2012; Llacuna et al. 2016) and were minimally observed in the sampling sites. Low abundance of holothuroidea species can be attributed to different human activities that directly affect immediate intertidal ecosystems (Llacuna et al. 2016). Several disruptive anthropogenic activities were noticed in the area like improper waste disposal in nearby communities, gleaning activities, active fishing

Table 1. Establishment of sampling plots and their respective coordinates

\begin{tabular}{|c|c|c|}
\hline Barangay & Legend & Coordinates \\
\hline \multirow[t]{4}{*}{ Vinapor } & V1 & $9^{\circ} 5^{\prime} 34.33^{\prime \prime} \mathrm{N}, 125^{\circ} 13^{\prime} 7.52^{\prime \prime} \mathrm{E}$ \\
\hline & $\mathrm{V} 2$ & $9^{\circ} 5^{\prime} 28.38^{\prime \prime} \mathrm{N}, 125^{\circ} 13^{\prime} 11.31^{\prime \prime} \mathrm{E}$ \\
\hline & V3 & $9^{\circ} 5^{\prime} 19.38^{\prime \prime} \mathrm{N}, 125^{\circ} 13^{\prime} 13.32^{\prime \prime} \mathrm{E}$ \\
\hline & V4 & $9^{\circ} 5^{\prime} 11.48^{\prime \prime} \mathrm{N}, 125^{\circ} 13^{\prime} 12.12^{\prime \prime} \mathrm{E}$ \\
\hline \multirow[t]{4}{*}{ Goso-on } & G1 & $9^{\circ} 4^{\prime} 58.26^{\prime \prime} \mathrm{N}, 125^{\circ} 13^{\prime} 22.97^{\prime \prime} \mathrm{E}$ \\
\hline & G2 & $9^{\circ} 4^{\prime} 50.33^{\prime \prime} \mathrm{N}, 125^{\circ} 13^{\prime} 23.59^{\prime \prime} \mathrm{E}$ \\
\hline & G3 & $9^{\circ} 4^{\prime} 39.95^{\prime \prime} \mathrm{N}, 125^{\circ} 13^{\prime} 23.90^{\prime \prime} \mathrm{E}$ \\
\hline & G4 & $9^{\circ} 4^{\prime} 29.27^{\prime \prime} \mathrm{N}, 125^{\circ} 13^{\prime} 24.36^{\prime \prime} \mathrm{E}$ \\
\hline
\end{tabular}


Table 2. Echinoderm species collected and identified at different sites in Goso-on and Vinapor, Carmen

\begin{tabular}{|c|c|c|c|c|c|c|c|c|c|}
\hline \multirow[t]{2}{*}{ Class } & \multirow[t]{2}{*}{ Species } & \multicolumn{8}{|c|}{ Sites } \\
\hline & & V1 & V2 & V3 & V4 & G1 & G2 & G3 & G4 \\
\hline \multirow[t]{5}{*}{ Asteroidea } & Acanthaster planci Linnaeus, 1758 & $\times$ & $\times$ & & & $\times$ & & & $\times$ \\
\hline & Choriaster granulatus Lütken, 1869 & & $x$ & & & & & & \\
\hline & Culcita novaeguineae Müller \& Troschel, 1842 & & & $x$ & & & & & \\
\hline & Linckia laevigata Linnaeus, 1758 & $x$ & $x$ & & $\times$ & $x$ & $\times$ & $x$ & $x$ \\
\hline & Protoreaster nodusus Linnaeus, 1758 & $x$ & $x$ & $x$ & & $x$ & $x$ & $x$ & $x$ \\
\hline \multirow[t]{6}{*}{ Echinoidea } & Astropyga radiata Leske, 1778 & & & $x$ & & & & & \\
\hline & Diadema setosum Leske, 1778 & $x$ & $\times$ & & & $x$ & $\times$ & $\times$ & $x$ \\
\hline & Echinometra mathaei Blainville, 1825 & & & $x$ & & & & & $x$ \\
\hline & Echinotrix calamaris Pallas, 1774 & $x$ & & & $x$ & & & & \\
\hline & Salmacis sphaeroides Linnaeus, 1758 & & & $\times$ & & & & & \\
\hline & Tripneustes gratilla Linnaeus, 1758 & & $x$ & $x$ & & & $x$ & $x$ & \\
\hline \multirow[t]{7}{*}{ Holothuroidea } & Bohadschia argus Semper, 1868 & $x$ & & & & & & & \\
\hline & Bohadschia koellikeri Semper, 1868 & & & & & $x$ & & & \\
\hline & Bohadschia vitieinsis Semper, 1868 & & $x$ & & & & & & \\
\hline & Holothuria leucospilota Brandt, 1835 & & $x$ & & & & & & \\
\hline & Holothuria fuscopunctata Jaeger, 1833 & & & $\times$ & & & $\times$ & & \\
\hline & Holothuria scabra Jaeger, 1833 & & & & & & & $x$ & \\
\hline & Pearsonothuria graeffei Semper, 1868 & $x$ & & & & & & & \\
\hline
\end{tabular}

in deeper portions, and recreational bathing in shallow parts. Many species were collected compared to the studies conducted by Walag and Canencia (2016) and Llacuna et al. (2016) since the sampling sites were established near their respective marine sanctuaries that have been protected and conserved by local authorities. Meanwhile, the number of species identified is very minimal compared to the study by Sadhukhan and Raghunathan (2011), where 57 species were collected in rocky and sandy shore within a healthy ecosystem in Rutland Island, South Andaman. This can be due to the healthy coralline ecosystem which is considered to be habitat and source of food for these marine organisms. Furthermore, it was also emphasized that the quality of environment of these organisms plays an important role in their distribution since they are sessile and slow moving animals (Sadhukhan, Raghunathan 2011).

\section{Species identification and characterization}

The 18 echinoderms species collected were described and characterized.

A. planci (Fig. 2A) is commonly known as crown-ofthorns sea star. This species is widely distributed throughout the Indo-Pacific Region and is particularly common on the Great Barrier Reef in Australia (Moran, 1988). A. planci bear 8 to 21 arms, radiating from a central disc. Adults of A. planci are normally 250 to $350 \mathrm{~mm}$ in diameter, while some individuals are over $700 \mathrm{~mm}$ in diameter (Humphreys, Humphreys, 1981). The mouth can be found on the underside of the central disc while light-sensitive eyespots are found at the tips of the arms. Individual colouration varies from red and orange to purple, which can be attributed to diet (Moran, 1988; Schoppe, 2000).
C. granulatus (Fig. 2B) is commonly known as granular sea star, which can be found singly or in groups all over reefs and in rocky substrates. Colour has been found to vary from place to place (Bos et al. 2008). This organism possesses an arsenal of hydraulic tube feet connected to an elaborate water-vascular system that surrounds the mouth, extending through five radial canals down the central disc (Schoppe 2000).

C. novaeguineae (Fig. 2C) is commonly called cushion star. It is pentagonal in shape and appears to be inflated with an abbreviated arms. Tube feet are found on the underside with its central mouth. The colour can vary from a mottling with darker and lighter shades of fawn, brown, orange, yellow and green. The body wall is made of calcareous ossicles, supported internally by pillars, where body cavity is filled with water (Mah 2017; Schoppe 2000).

L. laevigata (Fig. 2D) prefer benthic, inshore, continental shelf, coral reef ecosystems. These organisms are characterized by a uniformly blue, grey, pink, purple or fawn all throughout the body although specimens in the Pacific are all shades of blue (Schoppe 2000). These organisms exhibit their color from a blue pigment called linckiacyanin and some accessory yellow carotenoids (Clark, Rowe, 1971).

P. nodosus (Fig. 2E) can be found in tropical, Indo-westcentral Pacific Ocean with a depth of 0 to $30 \mathrm{~m}$ ranging from benthic and inshore ecosystems. It is quite abundant in the areas of Guam, New Caledonia, Ceylon, East Indies, north Australia, Philippine, China, south Japan and South Pacific Islands. These organisms are characterized by yellow tubercles with orange tips (Humphreys, Humphreys 1981; Schoppe 2000). 

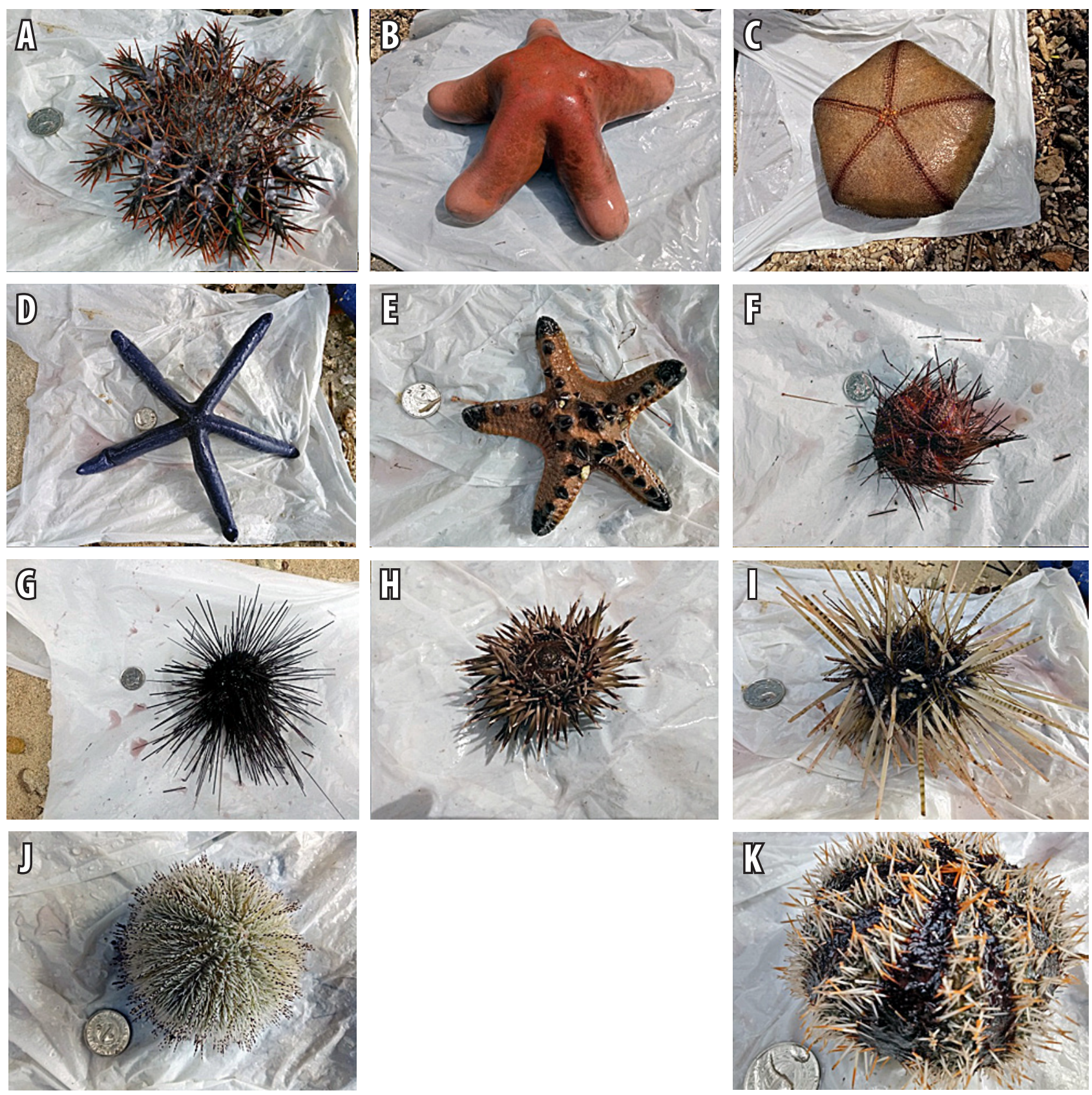

Fig. 2. Different species of sea stars and sea urchins collected from Goso-on and Vinapor, Carmen. A, Acanthaster planci; B, Choriaster granulatus; C, Culcita novaeguineae; D, Linckia laevigata; E, Protoreaster nodosus; F, Astropyga radiata; G, Diadema setosum; H, Echinometra mathaei; I, Echinotrix calamaris; J, Salmacis sphaeroides; K, Tripneustes gratilla.

A. radiata (Fig. 2 F) can reach up to a diameter of $20 \mathrm{~cm}$ with a flattened or slightly concave on the aboral side of its body. The spines can reach up to $4 \mathrm{~cm}$ long, grouped in five vertical clusters. In between these are $\mathrm{V}$-shaped areas with no corresponding spines due to the interambulacral plates (Clark, Rowe 1971). These areas with no spine are characterized by red with lines of iridescent blue dots. The colour of the rest of the spines differs from reddish brown to purple, dark brown or even nearly black (Clark, Rowe 1971; Schoppe 2000).

D. setosum (Fig. 2G) is one of the most common intertidal sea urchins in the tropical indo-pacific, especially in coralline ecosystems. They are believed to have an important ecological role, especially in grazing algae (Clark, Rowe, 1971). Its tests are slightly dorso-ventrally compressed which long spines protrude outward from the center of the body. The spines are extremely long and narrow relative to its body. The spines are often black although some are brown-banded. This diadema can be distinguished based on the presence of five white spots on its test, found between the urchin's ambulacral grooves (Schoppe 2000). 

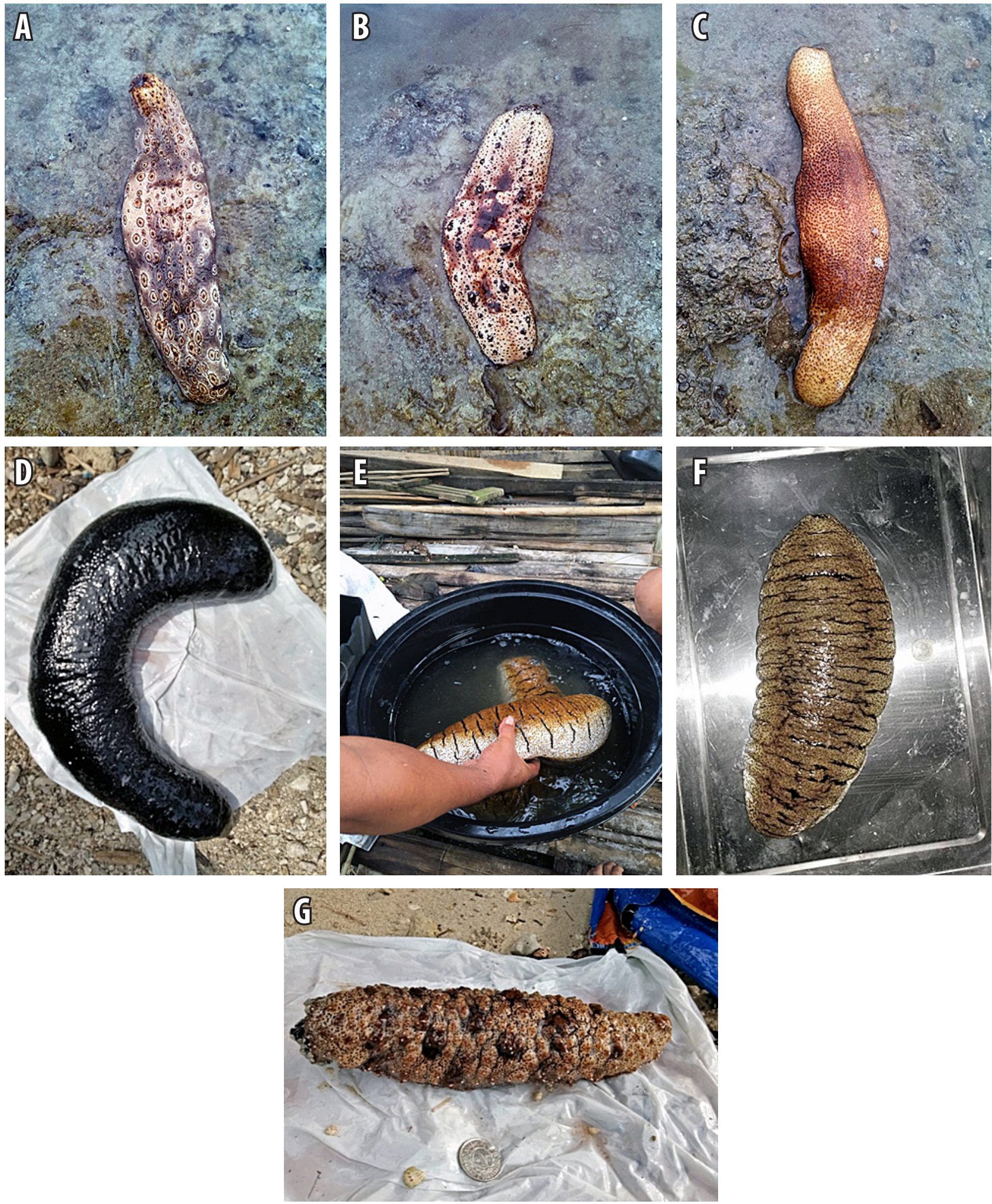

Fig. 3. Different species of sea cucumbers collected from Goso-on and Vinapor, Carmen. A, Bohadschia argus; B, Bohadschia koellikeri; C, Bohadschia vitensis; D, Holothuria leucospilota; E, Holothuria fuscopunctata; F, Holothuria scabra; G, Pearsonothuria graeffei.

E. mathaei (Fig. 2H) has a dark maroon to dark brown colour with spherical shape, exhibiting pentamourous symmetry. The test is surrounded by short spines extending outwards in all directions (Clark, Rowe 1971). The spines on the ventral surface are smaller in size and are separated in the center. Spines are similarly smaller on the aboral 
surface with color ranging from various shades of green, gray and purple. A unique characteristic that can be used to distinguish this organism is the pale ring found at the base of each spine (Schoppe 2000).

E. calamaris (Fig. 2I) are found in Indo-Pacific ocean at depths 0 to $90 \mathrm{~m}$ (Clark, Rowe 1971) and is characterized by a purplish to brown oval test with two sets of spines (Humphreys, Humphreys 1981). The spines are hollow and blunt and are grouped such that five bare zones appear on the central part of the test, which can be coloured, often blue (Schoppe 2000).

S. sphaeroides (Fig. 2J) is a medium-sized urchin with many thin spines that are relatively short (Clark, Rowe, 1971). It is usually found covering itself with debris and shells for camouflage purposes against potential predators. The test of this urchin is generally greenish white with spines banded with maroon to purple dispersed throughout their entire lengths (Schoppe, 2000).

T. gratilla (Fig. $2 \mathrm{~K}$ ) are common to the water of IndoPacific, Red Sea and Hawaii. It is commonly known by the locals as "suwaki", an edible urchin exploited by locals It is usually dark in colour, but mostly bluish-purple with short white spines. The spines are generally orange in colour while some are orange-tipped or completely white (Clark, Rowe 1971; Schoppe 2000). This sea urchin inhabits intertidal to subtidal shallow reefs and seagrass beds.

B. $\operatorname{argus}$ (Fig. 3A) is a cylindrical, dorsally-arched, and flattened ventrally sea cucumber with podia on small, conical, and irregularly arranged smooth bivium (Schoppe 2000). The mouth is located on the ventral portion surrounded by 20 short and dark tentacles while the anus is found on the dorsal portion surrounded by 5 groups of papillae. Spicules are found on the ventral tegument with biscuit-like nodules, and sometimes with a small hole (Clark, Rowe 1971). This sea cucumber is found in shallow waters, particularly in coralline ecosystems, and has of little commercial value.

B. koellikeri (Fig. 3B) are found burrowed under sediments of reef flats, and release milky white and pointed Cuvierian tubules in large quantities especially when disturbed (Clark, Rowe 1971). This cucumber is characterized by a bold deep brown and beige camouflage pattern while its tube feet are wide spread over the surface, which give a white dotted surface (Humphreys, Humphreys 1981).

B. vitiensis (Fig. 3C) is similar to B. argus, it is a cylindrical, dorsally-arched, and flattened ventrally sea cucumber. This organism's mouth is ventrally surrounded by 20 small, yellowish short tentacles, while its bivium is yellow with brown bands and the trivium is lighter encircled with brown spots. Spicules are found on the ventral tegument with a variety of biscuit-like nodules and pseudo-rosettes with a few rods (Clark, Rowe 1971; Schoppe 2000).

H. leucospilota (Fig. 3D) is a widespread species in the Indo-Pacific region, South Africa, China, and up to
Australia and Hawaii It is characterized by a deep charcoal to grey colour on all surfaces except the tube feet, which is pale grey. The body is smooth and covered with soft papillae (Humphreys, Humphreys 1981). Its spicules are characterized by smooth, low spired tables, simple buttons, and with variable holes (Rowe 1969).

H. fuscopunctata (Fig. 3E) inhabits shallow waters up to 10 meters deep, with preference under coral rubbles and seagrass beds (Humphreys, Humphreys 1981). This organism is characterized by its loaf shape, with brown spot speckles on a white to yellow dorsum. Numerous black wrinkles boldly traverse the dorsum while its ventral body is white (Clark, Rowe 1971; Schoppe 2000). No Cuevierian tubules are present while its spicules are in the form of tables and buttons (Carpenter, Niem 1998).

H. scabra (Fig. $3 \mathrm{~F}$ ) is characterized by grayish-black colour on the dorsal side with dark traversing wrinkles but paler on the ventral side. This organism is flat and firm to pliable skin while its spicules are well developed tables, while Cuevierian tubules are also absent (Clark, Rowe 1971; Carpenter, Niem 1998; Schoppe 2000).

P. graeffei (Fig. $3 \mathrm{G}$ ) has a a subcylindrical, dorsally arched, and slightly flattened ventrally body. On the bivium, the conical papillae are sparsely distributed while the podia are long and large. The calcareous disc has an average diameter of $240 \mu \mathrm{m}$ (Carpenter, Niem 1998; Schoppe 2000). Pseudo-tables (large base with large holes) and rosette (numerous) spicules are found on the dorsal and ventral tegument (Carpenter, Niem 1998).

\section{Echinoderm conservation status}

The echinoderm species collected varied in terms of their conservation status (IUCN 2014). As shown in Table 3, only $H$. scabra was classified as endangered, while the rest of holothuroid species are least concern except for B. koellikeri and $B$. vitiensis. The rest of the asteroids and echinoids like P. nodosus, L. laevigata, D. setosum, and T. gratilla were not yet assessed due to their abundance in different marine environments. Both B. koellikeri and B. vitiensis are classified as data deficient. A taxon is categorized as data deficient when there is insufficient information to make a direct, or indirect, assessment of its risk of extinction based on its distribution and/or population status (IUCN). Furthermore, a taxon in this classification may be well studied, and its biology is well known, but the appropriate information on its abundance and distribution are insufficient. This further signifies the importance of conducting studies on the abundance and distribution of organisms under this category to provide sufficient information for further classification of threatened taxa.

The sea cucumbers $B$. argus, $H$. leucospilota, $H$. fuscopunctata, and $P$. graeffei were classified as least concern while $H$. scabra is endangered. It is very important to note that although these are classified as least concern, their populations are known to be decreasing, like these 
Table 3. Conservation status of echinoderms in Goso-on and Vinapor, Carmen

\begin{tabular}{lll} 
Species & Common name & Conservation status \\
Acanthaster planci & Crown-of-thorns sea star, Dap-ag, Salamay & Not evaluated \\
Choriaster granulatus & Granular sea star & Not evaluated \\
Culcita novaeguineae & Cushion star & Not evaluated \\
Linckia laevigata & Blue linckia & Not evaluated \\
\hline Protoreaster nodusus & Horned sea star & Not evaluated \\
Astropyga radiata & Blue-spotted sea urchin & Not evaluated \\
\hline Diadema setosum & Long-spined sea urchin, Tuyom & Not evaluated \\
Echinometra mathaei & Burrowing sea urchin, Tuyom & Not evaluated \\
\hline Echinotrix calamaris & Banded sea urchin, Tuyom & Not evaluated \\
Salmacis sphaeroides & Green-spined salmacis, Tuyom & Not evaluated \\
\hline Tripneustes gratilla & Striped sea urchin, Suwaki & Not evaluated \\
Bohadschia argus & Leopardfish, Balat & Least concern \\
\hline Bohadschia vitiensis & Brown sandfish, Pulutan & Data deficient \\
Bohadschia koellikeri & Blackspotted sea cucumber, Balat & Data deficient \\
\hline Holothuria leucospilota & White thread fish, Balat & Least concern \\
\hline Holothuria foscupunctata & Trunkfish, Balat & Least concern \\
\hline Holothuria scabra & Golden sandfish, Putian, Curtido, Kagisan & Endangered \\
\hline Pearsonothuria graeffei & Blackspotted sea cucumber, Balat, Trompa & Least concern
\end{tabular}

of B. vitiensis and H. scabra. These organisms are heavily exploited in the Philippines and there is limited scientific information available needed to support conservation and management of these marine organisms (Jontila et al. 2014). These organisms are at high risk due to unregulated collection for trading and local consumption particularly of H. scabra. Furthermore, it was also reported that the collection of sea cucumbers in the Philippines can be dated back to the late eighteenth century and most are processed into dried form and exported to China, Hong Kong, Singapore, South Korea, Taiwan, and Japan (Choo 2008). This can be one of the prevailing reasons why the sea cucumbers collected were classified as least concern to endangered, especially $H$. scabra, which has a very high commercial value in Asian countries, especially China and Japan.

\section{Conclusions}

The echinoderms along the intertidal zone of Goso-on and Vinapor, Carmen, Agusan del Norte, Philippines were initially surveyed for baseline information of echinoderm diversity and abundance using a modified belt transectsampling plot method. Eighteen species of echinoderms were collected; five from class Asteroidea, six from class Echinoidea, and seven from class Holothuroidea. In terms of visual observation of density per sampling plot established, the most abundant species were $P$. nodosus, L. laevigata, and D. setosum. These organisms are considered to be tolerant to pollution and various disruptive anthropogenic activities. Several sea cucumber species were also noted and it is good to note the presence of an endangered, commercially exploited sea cucumber $H$. scabra. Most of the sea cucumbers collected and identified were classified to be least concern although it was noted by IUCN that their populations were decreasing, especially of B. vitiensis and $H$. scabra. Furthermore, it is recommended that intensive follow-up studies must be conducted especially in monitoring the population of $H$. scabra and the rest of these marine echinoderms. Special protection and attention must also be given in conserving and improving the quality of the marine ecosystem.

\section{References}

Achacoso S., Walag A.M., Saab L. 2016. A rapid assessment of foliage spider fauna diversity in Sinaloc, El Salvador City, Philippines: a comparison between habitats receiving different degrees of disturbance. Biodiversity 17: 156-161.

Alvarado J.J., Guzman H.M., Breedy O. 2012. Distribution and diversity of echinoderms (Asteroidea, Echinoidea, Holothuroidea) in the islands of the Gulf of Chiriqui, Panama. Rev. Biol. Mar. Oceanogr. 47: 13-22.

Barnes R.D. 1987. Invertebrate Zoology. $5^{\text {th }}$ ed. Harcourt Brace Jovanovich College Publishers, Fort Worth.

Bordbar S., Anwar F., Saari N. 2011. High-value components and bioactives from sea cucumbers for functional foods - A review. Mar. Drugs 9: 1761-1805

Bos A.R., Alipoyo J.C.E, Cardona L.T., Gumanao G.S., Salac F.N. 2008. Population structure of common Indo-Pacific sea stars in the Davao Gulf, Philippines. Proceedings of $9^{\text {th }}$ Biannual Meeting Philippine Association of Marine Science. UPV J. Nat. Sci. 13.

Bos A.R., Gumanao G.S., Alipoyo J.C.E., Cardona L.T. 2008. Population dynamics, reproduction and growth of the IndoPacific horned sea star, Protoreaster nodosus (Echinodermata; Asteroidea). Mar. Biol. 156: 55-63.

Carpenter K.E., Niem V.H. (eds). 1998. FAO Species Identification Guide for Fishery Purposes. The living marine resources of the 
Western Central Pacific. Vol. 2. Cephalopods, crustaceans, holothurians and sharks. FAO.

Choo P. 2008. The Philippines: a hotspot of sea cucumber fisheries in Asia. Sea Cucumbers. A Global Review of Fisheries and Trade (FAO Fisheries and Aquaculture Technical Paper), pp. 119-140.

Clark A.M., Rowe F.W.E. 1971. Monograph of shallow-water IndoWest Pacific Echinoderms. Trustees of the British Museum (Natural History) 690: 1-238.

Hernández J.C., Brito A., García N., Gil-Rodríguez M.C., Herrera G., Cruz-Reyes A., Falcón M.J. 2006. Spatial and seasonal variation of the gonad index of Diadema antillarum (Echinodermata: Echinoidea) in the Canary Islands. Sci. Mar. 70: 689-698.

Humphreys W.F., Humphreys W.F. 1981. The Echinoderms of Kenya's Marine Parks and Adjacent Regions. Koninklijk Museum Voor Midden-Afrika.

IUCN. 2001 Categories \& Criteria (version 3.1). Retrieved from http://www.iucnredlist.org/static/categories_criteria_3_1

IUCN. 2014. IUCN Red List of Threatened Species.

Jontila J.B.S., Balisco R.A.T., Matillano J.A. 2014. The sea cucumbers (Holothuroidea) of Palawan, Philippines. AACL Bioflux 7: 194-206.

Lawrence J.M., Herrera J. 2000. Stress and deviant reproduction in echinoderms. Zool. Stud. 39: 151-171.

Llacuna M.E.J., Walag A.M.P., Villaluz E.A. 2016. Diversity and dispersion patterns of echinoderms in Babanlagan, Talisayan, Misamis Oriental, Philippines. Environ. Exp. Biol. 14: 213-217.

Mah C.L. 2017. Culcita novaeguineae Müller \& Troschel, 1842. In: Mah C.L. Retrieved October 22, 2017, from http://www. marinespecies.org/aphia.php? $\mathrm{p}=$ taxdetails\&id $=212298$

Moran P. 1988. Crown-of-thorns Starfish Question and Answers. Queensland: Australian Institute of Marine Science.

Müller A.M.F., Makropoulos V., Bolt H.M. 1995. Toxicological aspects of oestrogen mimetic xenobiotics present in the environment. Toxicol. Environ. News 2: 68-73.

Pechenik J.A. 2015. Biology of Invertebrates. $5^{\text {th }}$ Ed. McGraw-Hill Publishing.

Rowe F.W.E. 1969. A review of the family Holothuriidae (Holothurioidea: Aspidochirotida). Bulletin of the British Museum (Natural History) 18: 117-170.

Sadhukhan K., Raghunathan C. 2011. Diversity and distribution of Echinoderms in Rutland Island. Int. J. Adv. Biol. Res. 1: 87-92.

Schoppe S. 2000. Echinoderms of the Philippines: a guide to common shallow water sea stars, brittle stars, sea urchins, sea cucumbers and feather stars. Philippines: VISCA-GTZ Program on Applied Tropical Ecology, Visayas State College of Agriculture.

Sithik A.M.A., Thirumaran G., Arumugam R., Ragupathi R., Kannan R., Anantharaman P. 2009. Physico-chemical parameters of Holy Places Agnitheertham and Kothandaramar Temple; Southeast Coast of India. Am. Euras. J. Sci. Res. 4: 108-116.

Stöhr S., O’Hara T.D., Thuy B. 2012. Global diversity of brittle stars (Echinodermata: Ophiuroidea). PLoS One 7: e31940.

Tuapattinaja M.A., Pattikawa J.A., Natan Y. 2014. Community structure of Echinoderms at Tanjung Tiram, inner Ambon bay, Indonesia. AACL Bioflux 7: 351-356.

Vandenspiegel D., Lane D.J.W., Stampanato S., Jangoux M. 1998. The asteroid fauna (Echinodermata) of Singapore, with a distribution table and an illustrated identification to the species. Raffles Bull. Zool. 46: 431-470.

Walag A.M.P. 2017. Bioactivities of extracts from different marine organisms around the world (2000 to present). Biomed. J. Sci. Techn. Res. 1: 1-3.

Walag, A. M. P., \& Canencia, M. O. P. 2016. Physico-chemical parameters and macrobenthic invertebrates of the intertidal zone of Gusa, Cagayan de Oro City, Philippines. AES Bioflux 8: 71-82. 